\title{
Analisis Perbandingan Kepuasan Pasien terhadap Pelayanan Kebidanan pada Peserta BPJS (Badan Penyelenggara Jaminan Sosial) dan non BPJS di Ruang Bersalin RSUD Soegiri Lamongan Jawa Timur
}

\author{
Lilik Darwati ${ }^{1}$ \\ ${ }^{1}$ Universitas Islam Lamongan
}

Corresponding author: lilik darwati (lilik.dw.lamongan@gmail.com)

Received 19 September 2018; Accepted 20 September 2018; Published 24 September 2018

\begin{abstract}
ABSTRAK
Setiap pasien selalu mengharapkan pelayanan yang berkualitas sehingga dapat tercapai kepuasan. Oleh karenanya setiap unit pelayanan kesehatan harus memberikan pelayanan yang sama kepada setiap pasien baik sebagai pasien BPJS maupun non BPJS. Mengetahui perbedaan tingkat kepuasan pasien terhadap pelayanan kebidanan pada pasien BPJS dan Non BPJS di Ruang Nifas Kelas II RSUD Soegiri lamongan. Desain penelitian yang digunakan adalah observasional analitik yang dilakukan dengan metode cross sectional. Populasi adalah populasi terhingga (finite population) yaitu ukuran populasi yang besarnya masih bisa dihitung (cauntable) dengan sample 70 responden diambil dengan teknik purposive sampling. Variabel bebas adalah jenis kepesertaan pasien BPJS dan non BPJS terikatnya kepuasan terhadap pelayanan kebidanan. Data dikumpulkan menggunakan kuesioner dan dianalisis dengan uji Mann Whitney. Sebagian besar responden BPJS puas terhadap pelayanan kebidanan yaitu sebanyak 24 responden $(77,4 \%)$, hampir seluruh responden Non BPJS puas terhadap pelayanan kebidanan yaitu sebanyak 37 responden $(94,9 \%)$ dari total 39 responden dan tidak ada perbedaan tingkat kepuasan antara pasien peserta BPJS dan Non BPJS terhadap pelayanan kebidanan di ruang nifas kelas II RSUD Soegiri lamongan ( $\mathrm{p}=0,548>0,05$ maka Ho diterima). Jenis pembiayaan kesehatan (BPJS dan Non BPJS) tidak menjadi faktor yang berpengaruh terhadap kepuasan pasien terhadap pelayanan kebidanan di Ruang Nifas Kelas II RSUD Soegiri lamongan.
\end{abstract}

Kata kunci: Pasien BPJS dan non BPJS, tingkat kepuasan pasien terhadap pelayanan kebidanan

Copyright @ 2018 STIKes Surya Mitra Husada

All rights reserved.

This is an open-acces article distributed under the terms of the Creative Commons Attribution-ShareAlike 4.0 International License.

\section{PENDAHULUAN}

Kepuasan pasien menurut Rahmayanty 2013 adalah evaluasi positif dari dimensi pelayanan yang beragam. Pelayanan yang dievaluasi dapat berupa sebagian kecil dari pelayanan, seperti salah satu jenis pelayanan dari serangkaian pelayanan rawat jalan atau rawat inap, semua jenis pelayanan 
yang diberikan untuk menyembuhkan seorang pasien sampai dengan sistem pelayanan secara menyeluruh di dalam rumah sakit. Kajian tentang kepuasan seorang pasien harus dipahami sebagai suatu hal yang sangat banyak dimensinya atau variabel pengaruhnya.

Kualitas pelayanan kesehatan dapat dinilai dari beberapa aspek yaitu, reliability adalah penampilan fisik yang meyakinkan dan dapat dipercaya, tanggap meliputi ketanggapan, kemauan, kesiapan dan kecepatan petugas dalam pelayanan serta ketepatan waktu dalam memberikan pelayanan, kompetensi yaitu kompetensi tenaga kesehatan yang dibuktikan dengan latar belakan pendidikan baik formal maupun informal, accessibility yaitu kemudahan pasien dalam memperoleh pelayanan, etika petugas yaitu komunikasi yang baik, kredibilitas yaitu tingkat kepercayaan, keamanan dan yang terakhir adalah kelengkapan fasilitas. Jika semua dimensi tercapai dengan baik maka loyalitas pasien sebagai pelanggan akan terbentuk sebagai wujud kepuasannya (Satrianegara, 2014).

Permasalahan yang kompleks dan terus ada dalam bidang kesehatan khususnya kebidanan adalah kematian ibu dan bayi. Menurut Rachmaningtyas tahun 2014, tingginya angka kematian ibu pada tahun 2013 mencapai 5.019 jiwa atau 359 per 100.000 kelahiran hidup. Angka tersebut terus meningkat setiap tahun jika dilihat dari tahun 2012 yaitu 4.985 jiwa dan pada 2011 adalah 5.118 jiwa. Pelayanan kesehatan ibu dan bayi baru lahir yang berkualitas dapat mencegah tingginya angka kematian. Angka kematian bayi baru lahir di Indonesia yang ibunya mendapatkan pelayanan antenatal dan pertolongan persalinan oleh tenaga profesional adalah seperlima dari angka kematian pada bayi yang ibunya tidak mendapat pelayanan (UNICEF, 2012). Oleh sebab itu pelayanan kesehatan khususnya pelayanan kebidanan harus diberikan secara seksama agar perempuan dapat mencapai derajat kesehatan yang baik, karena bidan sebagai petugas kesehatan yang paling dekat dengan perempuan dalam masalah reproduksinya memiliki fungsi independen berupa pemenuhan kebutuhan rasa aman dan nyaman, cinta dan mencintai, harga diri, sampai aktualisasi diri (Mubarak, 2011).

Perwujudan pemenuhan derajat kesehatan adalah sebagai upaya agar masyarakat dapat memperoleh pelayanan kesehatan yang baik. Salah satunya adalah adanya asuransi kesehatan yang dimaksudkan untuk mencegah ketidak terjangkauan pelayanan kesehatan dari segi keuangan. Salah satu asuransi kesehatan yang ada saat ini adalah BPJS. Dalam pelaksanaannya yang tergolong baru, banyak permasalahan yang dialami pesertanya. Hal tersebut menjadi salah satu penghambat tercapainya pelayanan yang profesional dan berkualitas. BPJS terdiri dari PBJS kesehatan dan BPJS ketenagakerjaan dan mulai beroperasi pada 1 Januari 2014 (Kementrian Kesehatan RI, 2013).

Penerapan kebijakan kepesertaan BPJS ini masih banyak masyarakat yang belum memahami mekanisme pelayanan dalam programnya. Pandangan pasien terhadap BPJS masih kurang baik. Keluhan yang dirasa pasien kaitannya dengan pelayanan administrasi, perawat/bidan, dokter, fasilitas dan infrastruktur, obat dan administrasi keuangan. Kepuasan pasien dipengaruhi oleh kualitas pelayanan kesehatan dalam metode pembiayaan, yang dapat diwakilkan perbedaannya antara pasien pengguna BPJS dan umum (Sreenivas dan Babu, 2012).

Hasil penelitian Primatika Ambar Sari tahun 2015 kepuasan secara umum antara pasien BPJS dan pasien umum didapatkan rerata tingkat kepuasan pasien umum sebesar 106,14 sedangkan pada pasien BPJS sebesar 66,62. Dapat disimpulkan bahwa rerata skor tingkat kepuasan pasien umum lebih tinggi dibandingkan dengan pasien BPJS. Nilai p (sig) sebesar 0,001 telah memenuhi kriteria normal yaitu $\mathrm{p}<0,05$, sehingga dalam penelitian ini didapatkan perbedaan yang bermakna.

Hasil studi pendahuluan di RSUD soegiri lamongan pada didapatkan rata-rata kunjungan di perbulan pada Januari-Juni 2018, di ruang bersalin dan nifas rata-rata per bulan 140 pasien partus dalam hal ini mewakili pasien rawat inap, serta didapatkan data dari bulan Januari-Agustus 2018 proporsi pasien Non BPJS adalah 30,8\% dan pasien BPJS 69,2\%. Wawancara dengan Kepala ruang Nifas bahwa tidak ada perbedaan pelayanan kebidanan terhadap peserta BPJS maupun Non BPJS. Hasil wawancara kepada dua ibu post partum yang keduanya berstatus peserta BPJS dan Non BPJS didapatkan bahwa keduanya merasakan mendapatkan pelayan kebidanan yang sama. Oleh karena itu peneliti ingin membuktikan secara ilmiah bahwa tidak ada perbedaan kualitas pelayanan terutama pelayanan kebidanan yang berpengaruh pada kepuasan pasien seperti pada penelitian yang sudah dilakukan sebelumnya.

RSUD soegiri merupakan rumah sakit pusat rujukan milik pemerintah daerah Kota lamongan sekaligus rumah sakit terbesar di Kota lamongan tentunya menjadi tujuan semua kalangan masyarakat untuk memperoleh pelayanan kesehatan. Upaya untuk menjaga mutu sudah dilakukan, bagian 
pengendali mutu adalah Divisi Litbang yang terdiri dari satu tim beranggotakan tiga orang. Untuk mengetahui kualitas pelayanan kuesioner dibagikan kepada pasien oleh masing-masing unit pelayanan tiap 6 bulan sekali. Hasilnya akan disetorkan ke Divisi Litbang yang kemudian akan di rekap dan disampaikan hasilnya saat rapat struktural tiap satu minggu sekali. Pelaporan kualitas pelayanan tersebut direkap setiap satu tahun sekali dan diarsipkan.

Beberapa penjelasan diatas untuk menurunkan angka kematian ibu dan bayi penting adanya untuk meningkatkan kualitas pelayanan terutama pelayanan kebidanan di ruang nifas. Oleh karena itu peneliti ingin mengetahui tingkat kepuasan pasien terhadap pelayanan kebidanan yang diterima peserta BPJS dan Non BPJS di RSUDsoegiri lamongan. Diharapkan dengan penelitian ini dapat membantu pula Divisi Litbang untuk melakukan pemantauan kualitas pelayanan dan kepuasan pasien di RSUD soegiri lamongan

\section{METODE PENELITIAN}

Penelitian ini menggunakan rancangan observasional analitik yang dilakukan dengan metode cross sectional. Lokasi dalam penelitian ini adalah di RSUD soegiri lamongan. Waktu penelitian dilaksanakan bulan . Januari-Agustus 2018. Analisis statistik dilakukan dengan menggunakan teknik statistik menggunakan uji uji Mann-Whitney.

\section{HASIL}

Hasil analisis univariate didapatkan hampir seluruh responden dengan asuransi Non BPJS termasuk puas terhadap pelayanan kebidanan yaitu sebanyak 37 responden $(94,9 \%)$ dari total 39 responden, hampir seluruh responden dengan asuransi Non BPJS termasuk puas terhadap pelayanan kebidanan yaitu sebanyak 38 responden (95\%) dari total 40 responden. Dari kelompok BPJS didapatkan data terbanyak adalah puas (24 responden) dan Non BPJS paling banyak didapatkan data juga pada tingkat puas (37 responden). Guna membuktikan perbedaan ini signifikan atau tidak dilakukan analisis Man-Whitney

Berdasarkan hasil penelitian didapatkan tidak ada perbedaan tingkat kepuasan antara pasien peserta BPJS dan Non BPJS terhadap pelayanan kebidanan di ruang nifas kelas II RSUD soegiri lamongan ( $\mathrm{p}=0,548>0,05$ maka Ho diterima).

\section{PEMBAHASAN}

\section{Tingkat Kepuasan Pasien terhadap Pelayanan Kebidanan Pasien BPJS}

Berdasarkan tabel 4.7 diketahui sebagian besar responden dengan asuransi BPJS puas terhadap pelayanan kebidanan yaitu sebanyak 24 responden $(77,4 \%)$ dari total 31 responden.

Kepuasan menurut Oliver dalam (Sari, 2008) merupakan tingkat perasaan seseorang (pelanggan) setelah membandingkan antara kinerja atau hasil yang dirasakan (pelayanan yang diterima dan dirasakan) dengan yang diharapkan. Selanjutnya Rahmayanty (2013) mendefinisikan kepuasan pasien adalah evaluasi positif dari dimensi pelayanan yang beragam yang diberikan pemberi jasa pelayanan. Kepuasan adalah tingkat perasaan seseorang (pelanggan) setelah membandingkan antara kinerja atau hasil yang dirasakan (pelayanan yang diterima dan dirasakan) dengan yang diharapkannya (Sari, 2008). Wijono dikutip Nugroho (2009) mengungkapkan kepuasan pelanggan rumah sakit atau organisasi pelayanan kesehatan lain atau kepuasan pasien dipengaruhi banyak faktor antara lain pendekatan dan perilaku petugas, mutu informasi, prosedur perjanjian, waktu tunggu, fasilitas umum yang tersedia, fasilitas perhotelan untuk pasien seperti mutu makanan, pengaturan kunjungan dan "privasi" outcome terapi dan perawatan yang diterima. Selain itu juga dipengaruhi oleh faktor jenis kelamin, usia pasien, pendidikan, kominiksai terapeutik, sikap dan pendekatan stap, kualitas pelayanan (Budiastuti dalam Liestriana, 2010).

Hasil penelitian menunjukkan sebagian besar responden dengan asuransi BPJS puas terhadap pelayanan kebidanan. Hal ini dapat disebabkan oleh berbagai faktor. Mengacu kepada teori yang ada kepuasan akan terwujud jika pelanggan atau pasien mendapatkan pelayanan sesuai atau melebihi dari 
keinginan atau harapannya. Umumnya pasien datang mengharapkan cepat mendapatkan pelayanan, petugas konsistensi dalam memberikan pelayanan, penampilan secara fisik terlihat meyakinkan dan dapat dipercaya, memiliki keahlian dan pengetahuan yang sesuai dengan kebutuhannya, mudah dalam mendapatkan pelayanan, secara etika petugas terlihat sopan, hormat kepada pasien, terlihat adanya kesungguhan dalam melayani pasien, juga keramahtamahan dari setiap petugas kesehatan yang melayaninya. Kesan seperti ini adalah hal pertama yang terekam pasien untuk mendapatkan kepuasan.

Terwujudnya kesan tersebut tidak terlepas dari peran BPJS selama ini sebagai pihak ketiga dalam asuransi kesehatan. BPJS berwenang memberikan kontrol kepada pihak PPK (Pemberi Pelayanan Kesehatan). Monitoring dan evaluasi selama ini sudah jalan disamping adanya hotline service yang bisa dihubungi klien/pasien peserta BPJS. Adanya keluhan pasien yang sampai kepada pengelola BPJS akan menjadi bahan masukan kepada pihak PPK. Oleh karenanya pada saat ini banyak pihak PPK (puskesmas, rumah sakit, dokter keluarga) sudah memberikan pelayanan yang berkualitas sehingga mendekati harapan pelanggan (pasien).

Disamping faktor dari provider tersebut, masalah keinginan dan harapan pada dasarnya merupakan masalah yang sifatnnya subyektif. Oleh karenanya penilaian mengenai pemenuhan harapan juga sangat subyektif dan sangat tergantung dari penilaian subyektif pelanggan/pasien. Subyektifitas itu sendiri sangat dipengaruhi oleh karakteristik masing-masing orang, mulai dari latar belakang usia, pendidikan, pekerjaan, penghasilan maupun faktor yang lain. Berdasarkan hasil analisis diketahui pada responden dengan usia muda ( $<20$ tahun) semuanya puas yaitu 1 responden $(100 \%)$ dan pada responden paling tua (>35 tahun) hampir seluruhnya juga puas yaitu sebanyak 16 responden $(94,1 \%)$. Dapat diinterpretasikan bahwa hampir semua usia merasakan puas. Dalam hal ini dapat diasumsikan bahwa usia tidak berpengaruh secara signifikan namun usia muda lebih cepat puas. Asumsinya mereka belum banyak pengalaman dengan pelayanan dari unit yang lain sehingga belum banyak pembanding sistem pelayanan yang lebih baik dari yang diterima saat ini.

Faktor lain yang berpengaruh terhadap kepuasan pasien adalah latar belakang pendidikan. Teori yang ada menjelaskan bahwa tingkat pendidikan akan cenderung mambantu seseorang dalam melakukan penilaian terhadap suatu materi atau objek. Lebih lanjut juga dijelaskan berdasarkan hasil penelitian-penelitian yang ada sebelumnya didapatkan bahwa responden dengan tingkat pendidikan lebih rendah akan merasa lebih puas. Berdasarkan hasil analisis diketahui pada responden dengan pendidikan terendah (SMP) semuanya puas yaitu 1 responden (100\%) dan pada responden dengan pendidikan paling tinggi (PT) hampir seluruhnya juga puas yaitu sebanyak 30 responden $(85,7 \%)$. Hal ini dapat diinterpretasikan bahwa pelayanan yang diberikan kepada peserta BPJS memang dirasakan dapat memenuhi harapan pelanggan atau bahkan melebihi harapan mereka. Oleh karenanya meskipun dengan perbedaan latar belakang pendidikan yang ada dari terendah sampai tertinggi, mereka samasama merasakan telah mendapatkan pelayanan yang baik yang sudah sesuai dengan harapan atau kebutuhannya meskipun pada pendidikan terendah (SMP) semuanya sudah puas sementara yang PT tidak semuanya puas. Hal ini disebabkan semakin tinggi tingkat pendidikan seseorang, maka daya untuk mengkritisi segala sesuatu akan semakin meningkat.

Faktor lain yang dapat berpengaruh terhadap kepuasan pasien adalah latar belakang pekerjaan. Berdasarkan hasil analisis diketahui pada responden dengan tidak bekerja (ibu rumah tangga) didapatkan hampir seluruhnya puas yaitu 36 responden $(85,7 \%)$ sedangkan pada responden dengan pekerjaan PNS didapatkan hanya sebagian besar responden yang merasa puas yaitu sebanyak 6 responden (75\%). Hal ini disebabkan dengan pekerjaan sebagai ibu rumah tangga dapat diasumsikan pada umumnya memiliki keterbatasan penghasilan. Sebaliknya bagi yang bekerja misalnya PNS, mereka merasa memiliki penghasilan sendiri dan memiliki jabatan yang harus dihormati. Pada umumnmya yang kedua ini akan berimplikasi terhadap besarnya tuntutan pelayanan kesehatan. Semakin tinggi tuntutan pelayanan maka semakin sulit untuk mencapai titik kepuasan. Namun demikian ketika pelayanan benar-benar sudah disediakan menurut dimensi kualitas maka akan memenuhi tuntutan semua orang atau semua golongan. Terbukti berdasarkan hasil analisis diketahui pada responden dengan penghasilan terendah (2-2,5 juta) didapatkan hampir seluruhnya merasa puas terhadap pelayanan kebidanan yaitu sebanyak 39 responden $(88,6 \%)$ demikian juga pada responden dengan penghasilan tertinggi (>2,5 juta) hampir seluruhnya juga puas yaitu sebanyak 22 responden $(84,6 \%)$. Dapat diinterpretasikan bahwa pelayanan dapat memuaskan semua golongan ekonomi. 


\section{Pasien Non BPJS}

Berdasarkan tabel 4.8 diketahui hampir seluruh responden dengan asuransi Non BPJS termasuk puas terhadap pelayanan kebidanan yaitu sebanyak 37 responden $(94,9 \%)$ dari total 39 responden.

Sebagaimana telah diuraikan di atas bahwa pada prinsipnya kepuasan itu adalah tingkat perasaan seseorang (pelanggan) setelah membandingkan antara kinerja atau hasil yang dirasakan (pelayanan yang diterima dan dirasakan) dengan yang diharapkan. Rahmayanty (2013) juga mendukung definisi kepuasan pasien dengan menyatakan bahwa kepuasan itu merupakan evaluasi positif dari dimensi pelayanan yang beragam. dengan Wijono yang dikutip Nugroho (2009) menyatakan bahwa kepuasan pelanggan di rumah sakit atau organisasi pelayanan kesehatan lainnya dipengaruhi banyak faktor antara lain pendekatan dan perilaku petugas, mutu informasi, prosedur perjanjian, waktu tunggu, fasilitas umum yang tersedia, fasilitas perhotelan untuk pasien seperti mutu makanan, pengaturan kunjungan dan "privasi" outcome terapi dan perawatan yang diterima. Selain itu juga dipengaruhi faktor jenis kelamin, usia pasien, pendidikan, kominiksai terapeutik, sikap dan pendekatan stap, kualitas pelayanan (Budiastuti dalam Liestriana, 2010).

Jika hasil penelitian menunjukkan hampir seluruh responden dengan asuransi Non BPJS termasuk puas terhadap pelayanan kebidanan, maka hal ini juga dapat disebabkan oleh berbagai faktor. Pasien non BPJS umumnya mereka mampu membayar sendiri biaya pelayanan kesehatan yang sudah dilaksanakan. Mereka bebas memilih kelas pelayanan yang disediakan sesuai dengan kemampuannya. Umumnya dengan beban harus mengeluarkan biaya seperti ini maka mereka menuntut adanya pelayanan yang baik atau yang bermutu. Disisi lain petugas kesehatan juga merasa bahwa pasien yang dilayani adalah orang yang mampu yang dapat membayar secara langsung atas biaya pelayanan kesehatan. Secara psikologis akan memberikan dampak tersendiri bagi provider untuk memberikan pelayanan terbaik bahkan jika mungkin juga berlebih. Tidak heran jika selama ini ada asumsi di masyarakat bahwa pelayanan bagi pasien non BPJS akan lebih baik jika dibandingkan dengan pasien BPJS.

Mengingat hal tersebut di atas maka dapat diasumsikan bahwa bagi pasien non BPJS akan cenderung bisa mendapatkan pelayanan yang sesuai atau bahwa melebihi dari keinginan atau harapannya. Umumnya pasien non BPJS akan mengharapkan pelayanan dengan cepat, tepat, konsistensi, termasuk fasilitas atau sarana dan prasarana atau penampilan secara fisik terlihat meyakinkan, petugas terlihat ahli dan memiliki pengetahuan yang sesuai harapannyanya, mudah secara administrasi untuk mendapatkan pelayanan, petugas sopan, ramah, tamah dan hormat kepada pasien, terlihat kesungguhannya dalam memberikan pelayanan kepada pasien.

Disamping faktor di atas terwujudnya kepuasan pasien non BPJS juga terkait dengan karakteristik masing-masing pasien, mulai dari latar belakang usia, pendidikan, pekerjaan, penghasilan maupun faktor yang lain. Berdasarkan hasil analisis diketahui pada responden dengan usia muda ( $<20$ tahun) semuanya puas yaitu 1 responden $(100 \%)$ dan pada responden paling tua $(>35$ tahun) hampir seluruhnya juga puas yaitu sebanyak 16 responden $(94,1 \%)$. Dapat diinterpretasikan bahwa hampir semua usia merasakan puas. Dalam hal ini dapat diasumsikan bahwa usia tidak berpengaruh secara signifikan terhadap kepuasan pasien, namun terlihat bahwa usia muda lebih cepat puas dibandingkan usia yang lebih tua. Asumsinya mereka belum banyak pengalaman dengan pelayanan dari unit yang lain sehingga belum banyak pembanding kualitas pelayanan yang lebih baik dari yang diterima saat ini dan belum tinggi tuntutan akan pelayanan yang bermutu.

Faktor lain yang berpengaruh terhadap kepuasan pasien adalah latar belakang pendidikan. Tingkat pendidikan akan cenderung mambantu seseorang dalam melakukan penilaian terhadap suatu materi atau objek. Berdasarkan hasil penelitian sebelumnya didapatkan bahwa responden dengan tingkat pendidikan lebih rendah akan merasa lebih puas. Berdasarkan hasil analisis diketahui pada responden dengan pendidikan terendah (SMP) semuanya puas yaitu 1 responden (100\%) dan pada responden dengan pendidikan paling tinggi (PT) hampir seluruhnya juga puas yaitu sebanyak 30 responden $(85,7 \%)$. Hal ini dapat diinterpretasikan bahwa pelayanan yang diberikan kepada peserta non BPJS memang dirasakan dapat memenuhi harapan semua pelanggan atau bahkan melebihi harapan mereka. Oleh karenanya meskipun dengan perbedaan latar belakang pendidikan yang ada, 
mereka sama-masa merasakan telah mendapatkan pelayanan yang baik yang sudah sesuai dengan harapan atau kebutuhannya.

Faktor lain yang dapat berpengaruh terhadap kepuasan pasien adalah latar belakang pekerjaan. Berdasarkan hasil analisis diketahui pada responden dengan tidak bekerja (ibu rumah tangga) didapatkan hampir seluruhnya puas yaitu 36 responden $(85,7 \%)$ sedangkan pada responden dengan pekerjaan PNS didapatkan hanya sebagian besar responden yang merasa puas yaitu sebanyak 6 responden (75\%). Hal ini disebabkan dengan pekerjaan sebagai ibu rumah tangga umumnya memiliki keterbatasan penghasilan. Sebaliknya bagi yang bekerja misalnya PNS, mereka merasa memiliki penghasilan sendiri dan memiliki jabatan yang harus dihormati. Pada umummya akan berimplikasi terhadap besarnya tuntutan akan pelayanan kesehatan yang baik. Semakin tinggi tuntutan pelayanan maka semakin sulit untuk mencapai titik kepuasan. Namun demikian ketika pelayanan benar-benar sudah disediakan menurut dimensi kualitas maka akan memenuhi tuntutan semua orang atau semua golongan. Terbukti berdasarkan hasil analisis diketahui pada responden dengan penghasilan terendah (2-2,5 juta) hampir seluruhnya merasa puas terhadap pelayanan kebidanan yaitu sebanyak 39 responden $(88,6 \%)$ demikian juga pada responden dengan penghasilan tertinggi (>2,5 juta) hampir seluruhnya juga puas yaitu sebanyak 22 responden $(84,6 \%)$. Dapat diinterpretasikan bahwa pelayanan dapat memuaskan semua golongan ekonomi dari pasien non BPJS.

\section{Perbedaan Tingkat Kepuasan antara Pasien Peserta BPJS dan Non BPJS terhadap Pelayanan Kebidanan}

Berdasarkan tabel 4.7 diketahui pada responden yang bersalin di RSUD soegiri lamongan pada pasien BPJS sebagian besar (24 responden/77,4\%) pasien puas terhadap pelayanan kebidanan dari total 31 responden, sedangkan pada Pasien Non BPJS didapatkan data yang sama yaitu sebagian besar (37 responden/94,9\%) responden puas terhadap pelayanan kebidanan dari total 39 responden. Berdasarkan tabel 4.15 diketahui tidak ada perbedaan tingkat kepuasan antara pasien peserta BPJS dan Non BPJS terhadap pelayanan kebidanan di ruang nifas kelas II RSUD soegiri lamongan ( $\mathrm{p}=$ 0,548>0,05 maka Ho diterima).

Badan Penyelenggara Jaminan Sosial atau (BPJS) merupakan lembaga yang dibentuk untuk menyelenggarakan program jaminan sosial di Indonesia menurut Undang-undang Nomor 40 Tahun 2004 dan Undang-undang Nomor 24 Tahun 2011.Sesuai Undang-undang Nomor 40 Tahun 2004 tentang Sistem Jaminan Sosial Nasional, BPJS merupakan badan hukum nirlaba. Pasien BPJS berarti pasien yang sudah terdaftar program jaminan sosial di Indonesia. Dalam kontek ini pasien BPJS berbeda dengan non BPJS dilihat dari aspek pembiayassan kesehatan. Dalam ppasienngan medis kedua jenis pasien ini adalah sama sehingga harus mendapatkan pelayanan yang sama. Oleh karenanya petugas kesehatan harus tetap bekerja secara profesional. Dalam penelitian Burhan (2014), sebagai panduan dalam menilai profesionalisme, Arnold dan Stern (2006) memberikan definisi bahwa profesionalisme ditunjukkan melalui sebuah dasar kompetensi klinis, kemampuan berkomunikasi, pemahaman etika dan hukum yang dibangun oleh harapan untuk melaksanakan prinsip profesionalisme.

Tidak adanya perbedaan tingkat kepuasan antara pasien peserta BPJS dan Non BPJS terhadap pelayanan kebidanan disebabkan petugas kesehatan sudah tidak membeda-bedakan pasien dalam memberikan pelayanan. Apapun jenis pasien (BPJS ataupun Non BPJS) semua akan diperlakukan sama, dilayani dengan sama, yakni sama-sama cepat, sama-sama mendapatkan fasilitas fisik atau sarana dan prasarana yang sama baiknya sesuai dengan kelasnya, sama jenis obat yang diberikan uang sesuai stpasienr yang telah ditetapkan BPJS, ruang rawat inap juga sama, keramahan petugas dalam memberikan pelayanan juga sama, dan semua pendukung yang lainnya juga sama. Jika sudah demikian maka pasien merasa sudah mendapatkan pelayanan yang sama baiknya antara peserta BPJS maupun non BPJS. Saat ini petugas kesehatan juga tidak berani membedakan kualitas dalam pelayanan. Monitoring dan evaluasi pelayanan sudah dilaksanakan secara periodik kepada PPK (pemberi pelayanan kesehatan) atau kepada provider (petugas kesehatan) oleh pihak BPJS. Dalam arti peserta BPJS dijamin kualitas pelayanan yang akan diterima dengan pasien non BPJS. Petugas BPJS dengan ketat memberikan persyaratan sarana dan prasarana yang harus dipenuhi PPK (pemberi 
pelayanan kesehatan) bagi papsien BPJS. Adanya persyaratan demikian ini maka pasien akan samasama merasa puas terhadap pelayanan yang diterima.

Selanjutnya berdasarkan olah data diagram kartesius dapat diketahui bahwa nilai harapan lebih besar dari nilai kenyataan, yaitu Kinerja Pelayanan (X) 3,74 dan Harapan (Y) 4,82. Secara umum dapat diinterpretasi bahwa pasien belum puas karena nilai harapan masih lebih besar daripada kinerja pelayanan. Artinya masih berada di Kuadran A : Perioritas Utama yang artinya adalah kinerja suatu variabel lebih rendah dari keinginan konsumen sehingga rumah sakit harus meningkatkan kinerjanya agar lebih optimal. Banyak hal yang masih perlu pembenahan diantaranya jika dilihat per item penilaian, rata-rata terendah dari kinerja pelayanan adalah item nomor 17 dengan rata-rata 3,59 (penampilan bidan rapi dan menyenangkan). Hal ini berarti bahwa pasien masih kategori puas saja terhadap penampilan bidan. Demikian juga dengan item yang lain yang secara keseluruhan hanya sampai kategori puas dan tidak ada yang sangat puas, seperti item nomor 20 (petunjukarah yang jelas) hanya 3,70 (puas). Hal ini berarti pasien sudah menilai puas dengan petunjuk arah yang ada saat ini namum masih belum sangat puas yang berarti masih perlu ditingkatkan kejelasan dan kemudahan petunjuk arah yang ada di rumah sakit saat ini.

Hal ini juga terlihat pada item nomor 21 (lokasi ruang nifas mudah dijangkau), rata-rata juga hanya 3,70 (puas). Hal ini berarti pasien sebenarnya masih memiliki harapan yang lebih mengenai lokasi ruang nifas karena belum bisa sangat puas. Oleh karenanya perlu penataan yang lebih baik mengenai akses menuju ke ruang nifas agar lebih mudah lagi dijangkau pasien. Termasuk pula item nomor 22 (kemudahan pasien dan keluarga cukup menghubungi bidan jika memerlukan suatu tindakan atau informasi tertentu) hanya mendapatkan nilai rata-rata 3,70 (puas). Hal ini berarti pasien memang sudah puas akan tetapi masih perlu ditingkatkan lagi kemudahannya agar pasien sangat puas.

\section{KESIMPULAN DAN SARAN}

Sebagian besar responden dengan asuransi BPJS puas terhadap pelayanan kebidanan yaitu sebanyak 24 responden $(77,4 \%)$ dari total 31 responden.

Hampir seluruh responden dengan asuransi Non BPJS termasuk puas terhadap pelayanan kebidanan yaitu sebanyak 37 responden $(94,9 \%)$ dari total 39 responden.

Tidak ada perbedaan tingkat kepuasan antara pasien peserta BPJS dan Non BPJS terhadap pelayanan kebidanan di ruang nifas kelas II RSUD Gambiran Kediri ( $\mathrm{p}=0,548>0,05$ maka Ho diterima).

\section{DAFTAR PUSTAKA}

Burhan, Fatmadina. (2014). Penilaian terhadap Profesionalisme Dokter di Unit RawatJalan RSUP Haji Adam Malik Medan. Skripsi untuk Memperoleh Sarjana Kedokteran Universitas Sumatra Utara Medan: Diterbitkan di 123dok.com

Liestriana. (2010). Hubungan Komunikasi Terapeutik dengan Kepuasan Pasien Pasca Operasi Rawat Inap di RSUD Kajen Kabupaten Pekalongan.

Nugroho, Haryanto Adi \& Septyani, Aryati. (2009). Hubungan antara Komunikasi Terapeutik Perawat dengan Kepuasan Pasien di Rumah Sakit lslam Kendal. FIKkUS Jurnal Keperawatan Vol. 2 No. 2 Maret 2009 : 36-41

Rahmayanty, Nina. (2013). Manajemen Pelayanan Prima (Mencegah Pembelotan dan Membangun Customer Loyality. Yogyakarta: GrahaIlmu

Sari, Irine Diana. (2008). Manajemen Pemasaran Usaha Kesehatan. Yokyakarta: Mitra Cendikia Press 